\title{
Directors' Remuneration and Corporate Governance within the UK
}

\author{
Tasnuva Jahan (Corresponding author) \\ LLM International Commercial Law \\ Bournemouth University, UK \\ E-mail: tas991@yahoo.co.uk
}

Received: June 26, 2017 Accepted: July 4, 2017 Published: July 10, 2017

doi:10.5296/ijld.v7i3.11496ＵRL: https://doi.org/10.5296/ijld.v7i3.11496

\begin{abstract}
In this era of globalization and rapid growth of world economy size of directors' remuneration is a matter of international debate. Current anxieties are around the increase in executive pay as reports disclose that executive pay no longer corresponds with performance and the gap of wealth have widened since the 1980s. The courts, nevertheless, has been reluctant to scrutinise this condition, neither has the legislature shown any interest to fix any standard of pay. Model Articles for Public Companies allow the board of directors to delegate their powers on conditions they seem fit. Compared the pay of CEOs of companies of Japan, Germany and UK with the USA and found that USA and UK were closest with their generous pay. This comparison is important since the UK and the USA have been taking serious techniques to prevent extra pay. This paper will discuss about the issues with remuneration highlighting the legal control of director's remuneration and the flaws of regulations from different viewpoints of shareholder, executive and company along with social and economic the factors that increases director's remuneration.
\end{abstract}

Keywords: Director, remuneration, economic growth, legal control, shareholders 


\section{Introduction}

Directors' remuneration is an important factor for corporate economic growth for many reasons and it is a complex issue to deal with. It has become more difficult since the financial crisis (Wells, 2015). After the economic problem, many countries including UK want to authorise regulatory reform so it can stop the problem that overwhelmed the financial market do not occur again (Arsalidou, 2011). Excessive remuneration is serious factor that shareholders are worried about and claimed that to be indicative of inadequate transparency and liability of management. It increases companies unnecessary cost also affect the shareholders negatively (Clark, Birds, \& Boyle, 2014, pp. 350-353). The rising interest in the mechanisms by which companies are owned and controlled agrees proof to the concept that the governance appliance may affect corporate performance. Corporate governance is the method by which companies are controlled, directed and made accountable (Note 1). Both the UK, and the USA, there has been a great debate whether the corporate control is an effective method for good corporate governance.

Increased shareholder involvement and regulatory analysis of the director's excessive remuneration also became a main concern for public. Public considers this pay increase in corporate sectors as a 'fat cat culture' (Joseph, 2012). There are many concerns that make remuneration as a big issue.

\section{Entitlement to Directors Remuneration}

Directors are the direct link between the shareholders and companies. They run company's business where the shareholders invest and return profit to them. (Dignam \& Lowry, 2012) Shareholders expect the directors to work according to the company guideline. Directors position in a fiduciary relationship with company. In their everyday duties, they must be careful of their accountabilities to the company, shareholders, personnel and the public overall (Davies, 2008). Their fiduciary duties are basically protected by variety of statutory provisions. Directors' fiduciary duty is related with the issue of remuneration. At present directors remuneration has been the topic of much debate and analysis as part of efforts to create good corporate governance management in the interest of shareholders and company resources (Dignam \& Lowry, 2012, n6).

In the case of Hutton $v$ West Cork (Note 2), Bowen L J opined that, a director as 'not a servant' and he is undertaking business for the company, however not on ordinary positions for which he is to be paid. Since then, there have been different views on entitlement of remuneration. In Guinness plc v Saunders (Note 3) held that this a legacy coming from the law of trust whereby a trustee is not allowed to remuneration unless the mechanism so provides that a director being a fiduciary is therefore in a comparable position to a trustee. Guinness plc v. Saunders (Note 1) recognised that courts are in no point to fix reasonable remuneration. The courts, however, has been unwilling to scrutinise this situation, neither has the legislature presented any interest to regulate any standard of pay (Davies, 2008).

According to section 172 of the Companies Act (C A) 2006, directors have responsibilities to promote company. Nevertheless, if directors allow themselves high remunerations, it is hard 
to prove if this is temporary or if they will help company in the long run (Dignam \& Lowry, 2012, n5, pp. 28-30). There is limited scope for disagreement if an independent remuneration committee commends the remuneration report and audit. Otherwise it is challenging to demonstrate that remuneration levels are too high (Lee, 2012).

Articles 19 (Note 4) and 23 (Note 5) of the Model Articles 2008 provide that directors are entitled to determine to remuneration for their service. Directors cannot be held liable to the company for their remuneration unless agreed otherwise by the directors. (Note 6)

Section 247 of Companies Act (CA) 2006 also deals with director's remuneration. A director is entitled to compensation for loss of office under sections 215 to 222 of CA 2006. Section 217 prevents a company from paying any director for loss of office without being disclosed and approved by the company (Dignam \& Lowry, 2012, n5, ch. 13).

\section{History of Corporate Governance in Listed Companies}

In the late 1980, UK reformed its regulation of the listed companies. It created for public doubt about big companies and they worked together with the Bank of England realise to the difficulties (Clark et al., 2011, pp. 360-365). After Enron scandal in the United States, the financial reporting committee revised the combined code. Over two decades the UK government has been trying to help committees on the issues of corporate governance. As a result of this, reports were published to help companies to develop corporate governance practice by recommending codes for best practice namely Cadbury, 1992, Greenbury 1995, Hampel, 1998, Higgs, 2003 etc. (Note 1)

The first form of Code was introduced by the Cadbury Committee on the Financial Aspects of Corporate Governance. Cadbury Report highlighted on Control and boards' reporting functions, auditors' roles for corporate failures, collapse of the banking sector and scandals such as BCCI (Note 7). Transparency was prerequisite on corporate governance in annual financial reporting (Note 8), accountability of listed companies and forming a remuneration committee. The report also focused that executive directors should not take part in determining their payment. The main stream of these approvals was applied by the London Stock Exchange though not enforceable (Clark et al., 2011, n3. Ch. 11).

The Greenbury Report highlighted companies to form a remuneration committee with non-executive directors to decide the remuneration packages for the executives, stock options and excess pay (Note 1). After the Greenbury report the restricted stock gained popularity and some firms also adopted the 'performance pay plans' that pays out for good performance but applying this policy did not work properly. But after that it also found out that the pay of managers increased comparing to the directors of other companies who were receiving higher (Cheffins \& Thomas, 2001).

Hampel Report endorsed Greenbury's observation that shareholder's vote on remuneration in company's annual meetings is unnecessary (Note 1). Again in 1999, The DTI paper published on executive pay which is different from the Greenbury and Hampel Committees and preferred shareholder voting. The DTI accepted that the board of directors, should start a general policy on executive pay and delimit the remuneration packages for directors (Conyon, 
\& Sadler, 2010).

The Directors' Remuneration Report (DRR) Regulations were published in 2002. According to the new regulations, it is now mandatory for all public companies to disclosure executive pay (Note 9) and directed shareholder sanction for the DRR. But this was only advisory not binding. A large number shareholders are not satisfied with executive pay compared to their performance. There were also protests when companies like WPP and AVIVA increased pay even after poor performances (London Stock Exchange, 2012).

Additionally, in July 2010 the (Financial Reporting Council) FRC (Note 10) introduced new UK Corporate Governance Code (the Code) replacing the Combined Code. The Code announced annual re-election of directors to provide shareholders the power to confirm competent directors on the board. According to principle D.1, that level of remuneration should be fixed to inspire directors and at the same time, not pay excessively. Principle D.2 deals with the definition of formal and transparent technique for setting remuneration (Dignam \& Lowry, 2012, n5, ch. 13). In 2012 the FRC agreed to discuss after the government's legislation on executive pay had been finalised (Note 11). The new conditions connected to voting on remuneration have been enacted in the Enterprise and Regulatory Reform Act 2013 (ERRA, 2013) (Note 10). This legislation added further requirements under section 421 of CA 2006 which requires detail disclosure of directors' pay out for Large and Medium Sized Companies and Groups Amendment 2013 (Large and Medium Sized Companies and Groups (Accounts and Reports) (Amendment) Regulations 2013, SI 2013/1981). Also, it requires companies to compare the directors pay increment with all employees pay increment (Note 1).

Moreover, High Pay Centre examined the effect of the legislation and their reports established that payments increased 5 percent in 2013 compared to 2012. It clarifies that companies have shadowed the provisions of the legislation but not strictly abided by it (High Pay Centre, 2014). And, in 2010 report of Lloyds Bank disclosed that chief executive officer Eric Daniel's, salary increased to £103, 5000 (Lloyds Banking Group PLC, 2010).

Recently, in 2014 The FRC's updated Code (Note 10) does not discuss details about remuneration policy except remuneration committee is recommended to avoid rewarding for poor performance. The Schedule A of the Code deals with the performance connected to the director's payment (Note 1). Principle D.1 was reviewed for confirmation for better emphasis on long time achievement of the company. The Code also recommended that companies should make provisions that will permit to recover or withhold pay when needed (Note 10).

UK does not have any prescribed structure for director's remuneration except in certain financial institutions for the Capital Requirements Directive and FSA Remuneration Code. Consequently, shareholders have settled their own payment guideline. Over the last decade this exercise influenced the remuneration policy (Lee, 2012).

\section{Factors Concerning Executive Remuneration}

There are a lot of reasons that increased executives' remuneration. Some of them are real, while others are baseless and unreasonable. Directors' pay was legitimately increased during 
the time when the country was financially doing well until the financial crisis started (Arora, 2012). During the financial well-being business was very profitable and the shareholders were making money through dividend payment (Kershaw, 2012). This eventually created a natural growth in executive pay. But after the financial breakdown this natural growth was revealed to be dangerous and it was found out to be an artificial profit which also led to some artificial increases in executive pay and in increased the levels of remuneration (Karmel, 2004).

Agency theory is considered one of the keystones of executive remuneration matters. An agency problem is expected in a big firm, where the ownership and controls are separated. Even though the board of directors takes decision and the executives execute them, but, there is a chance that executives can take benefit by their control power and use company's assets to improve their own way of life. It gives rise to agency costs (Cheffins, 2008, ch 14).

Remuneration of executive increases because the executives focus only in their personal interest ignoring shareholders' interests to get higher remuneration package which creates huge chaos on the sustainability of the overall economy (Note 1). Furthermore, executive payment is not only a part of the agency problem itself but also a possible device for addressing the agency problem (Karmel, 2004, n44).

Additionally, the alignment of remuneration of directors with the company's performance is one of the key and debatable pay concerns for shareholders. This is mostly regarding where director's remuneration and short-term incentive payments are growing, thus generating extra cost of company and payments of dividends have been denied. It is stressful when company's share price is dropping and an offer to increase remuneration has been provided (Nakajima \& Harry, 2012).

Another problem with increasing remuneration is lack of Connection between Performance and Payment. Companies' performance and external factors like world economy can affect stock prices (Hannigan, 2012). In some companies, the executive gets extra pay when the company's stock price goes up even if they are not entitled to that profit. When the stock price increases, all the companies take advantages of profit. Companies where the management is poor and suffers difficulties they do not award their executives due to decreased options and some executive also take the advantages of this situation (Note 1).

Executives' greed is another reason for high remuneration (Cheffins, 2008, n46). The 'two sides of coin' states that if it is used properly without any additional or deceitful activities, executive payment can link executives to enhance shareholder wealth. But the abusing of this corporate governance device can collapse managerial approach and moral threat. Large amount of executive remunerations drives the corporate power to nonexistence. It can show that there is no appropriate control in the company and shareholders' money is being wasted (Arye Bebchuk \& Fried, 2003).

In the United States of America (USA) shareholder's response to the regulation of executive remuneration is also debateable. Shareholder activists also criticised that these practices are unjustified because they cannot establish a fundamental link to pay and performance (Karmel, 
2008, n44). Accounting scandals of world famous companies like Enron, WorldCom, General Electric (GE), Royal Bank of Scotland (RBS), shows the tricky sides of executive remuneration process (Philip, 2015, n1). It is very complicated when directors can take advantage of 'off-balance sheet finance' (Copp, 2011) and the fraudulent activities by the directors can be hidden from shareholders and public for a long period time. So, the performance-based pay of executives worsens the agency problems instead of reducing them where and there is no alignment relating to their interests (Arora, 2012, n42).

\section{Regulatory Flaws in the Remuneration System}

More than Twenty years after the Cadbury report, the new regulations are still not able to slow down the remuneration packages the and it increases pressure on governments, regulators and companies to create new rules of corporate governance that might save the financial market from future financial crises that recently experienced (Cheffins \& Thomas, 2001). Current disclosure framework on remuneration works only partially. Also, there are some systematic flaws in regulations like de-regulation, light-touch regulation and the non-existent regulation that have allowed more risk to control remuneration and it failed to work in real life system (Philip, 2015, n1).

Annual reports are where the shareholders get detailed information on Public companies. It contains detailed information about companies' policy and procedure to make directors remuneration package (Note 12). Even though these reports include disclosure on payment, remuneration committee and counsellors, sometimes it looks to very long and complex (King, Pau, \& Grapsap, 2013). It often hides the key information about director's pay regarding the past fiscal year and future pay policy. HSBC's in 2010 published annual report with 396 pages. 14 pages of the report contained detail description of remuneration plan and directors pay. It also pointed out the inconsistencies in the current rules, as the determination of 'bonus' varies depending on if it is considered with the CA or the Listing Rules. In many cases full disclosures appear to mark main information ambiguous (Philip, 2015, n1).

Moreover, all companies need to provide information regarding directors' numeration package and the records to their annual accounts in accordance with C A, 2006 of s 412 and a quoted company must prepare a directors' remuneration report for each fiscal year under $\mathrm{s}$ 420 of C A 2006 (King, Pau, \& Grapsap, 2013, n60). But there is some weakness in account-based incentive where accounting profits are used as performance indicator. The directors can manipulate performance indicator in many ways. They can increase some activity cost so it will show company's future profit more than it is in the present (Dignam \& Lowry, 2012, n5, Ch. 13). So, it will increase their accounting profits. They can also change the financial statements the way they want to show higher profits in terms of their own preferences and at the end it will increase their payment. (Lee, 2012, n41)

In September 2011, the UK's Department for Business, Innovation and Skills (BIS) published two consultation papers related to changes to UK company law revealed some problems with the existing disclosure requirements. One of them regarding disclosures of annual reports of UK publicly traded companies (Note 14) and the other one regarding executive remuneration (Note 13). Both show concerns lacking clarity of method how decisions are being made to 
pay and connection between pay and performances about the complexity of the remuneration package and their disclosure. Even though the main concern of the paper is detailed that companies are required to disclose but it is complex and tough to determine how much they made in past and present performance (Conyon and Graham, 2010, n27). BIS also consulted on the shareholders voting rights related to the remuneration reports and exit payment of executives after their retirement (Note 16).

From side to side it is noted that, to control the executive pay as corporate governance mechanism has been tough due to the non-compliance with the disclosures where shareholders and investors are allowed to be provided by detailed statistics about executives' pay arrangements for a flawless image of company's policies and procedures. (Hannigan, 2012)

\section{International Context}

Procedures on executive remuneration vary from state to state and are to some point informed by broader national or traditional performs.

The United States introduced new disclosure requirements and a shareholder 'say on pay' by its the Dodd-Frank Wall Street Reform and Consumer Protection Act 2010 which is implemented by the Securities and Exchange Commission. The Act obliges publication of annual overall payment of executive, salary comparison of CEO pays and employee, the overview of 'claw-back policies' and new processes to avoid conflict of interest (Note 17).

The Australian government also faced problems with conflict of interest and they guided the company's remuneration committees on pay (Farrar, 2010). In 2011, result of reforms requires boards to disclose remuneration report and impose limits on the capacity of executive directors to involve remuneration consultants (Note 18). It also stipulates that listed company's remuneration reports also have a board's satisfaction declaration that directors do not have any influence on the remuneration package (Note 1). Australia also took actions to stop rewards for failure with a new shareholder vote on termination payments of more than one year's base remuneration (Note 1).

In Europe, different types of practices were implemented. In 2004, the EU Commission mentioned that public companies in Europe need to disclose remuneration policy and how individual executive are paid. But it is not legally mandatory, and there is a variety of compulsory disclosure systems (Ferrarini, Moloney, \& Ungureanu, 2010). The Commission also approved recommendations to confirm transparency of remuneration, control by shareholders and advisory vote and disclosure. The integrated recommendation mentioned long-term workability of the company and certification of performance based remuneration (Note 19).

Moreover, the idea of a remuneration cap gained popularity and political favour in international community as a way to decrease unnecessary remuneration (Ferrarini et al., 2010, n61). This method has been suggested in Europe for the tremendously high payment by several people in the banking sector. Additionally, two of Europe's most influential and advanced markets, Germany and France have measured and assessed the suggestion that 
there should be remuneration cap for directors (Hirt, 2004). Germany is one of the successful financial market in Europe and it introduced remuneration cap before the financial crisis started to stop director's pay increase but the concept did not work as they expected to because they found out that remuneration cap is not suitable in an open economy where it is directed by market principles and freedom of contract (Note 1).

There are few reasons why UK does not put any cap on directors. Directors are the main source of the company to bring large profit for the investors. Because of their work nature and responsibly they deserve higher pay (Note 1). Putting a cap on directors pay may discourage them to give their best to the company but their legitimately high incomes can give better opportunity to work. (Copp, 2011, n55).

\section{Conclusion}

Finally, the example of remuneration practices in the UK intended that there was an unsuitable incentive structure that did not furnish for long-standing results of business decisions and consequently increased the undesirable outcome of the financial crisis. Though there are noteworthy regulatory methods to limit the increase of director's remuneration and it has been very challenging. The current remuneration strategies weaken the traditional standard which provides that levels of pay should be satisfactory to attract, hold and inspire directors. The government still considers that executive skill is vital for companies but it is essential to have a highly talented executive for more income of company (Arora, 2012, $\mathrm{n} 42$ ). So, the UK should be a productive ground for business movement and improvement not one of fairness and equity. The crisis openly showed the widespread and noticeable defects within the regulatory system which were invented to avoid such extreme remuneration package. Controlling pay is not the appropriate solution for remuneration problem. A suitable corporate control mechanism is essential to make sure that there are proper controls in the company. Having scrutinised the practical and legal approach to executive remuneration, it is clear that the no corporate structure will always be flawless, but it is certainly the shareholders of company, and not government or regulators, who have the greatest inducements to improve structures that will certify that directors follow the goals of shareholders (Arsalidou, 2011, n2).

\section{References}

Abugu, J. E. (2011). Monitoring directors' remuneration, fat cat packages and perks of office. Journal of Financial Crime, 19(1), 6-19.

Arora, A. (2012). Remuneration practices in banks and other financial institutions: Part 1. Company law, 33(3).

Arsalidou, D. (2011). The regulation of executive pay and economic theory. Journal of Business Law, 2011(5), 431-456.

Arye Bebchuk, L., \& Fried, J. M. (2003). Executive compensation as an agency problem. The Journal of Economic Perspectives, 17(3), 71-92.

Cheffins, B. R. (2008). Company law: theory, structure, and operation. Oxford. 


\section{Macrothink}

International Journal of Learning and Development

ISSN 2164-4063 2017, Vol. 7, No. 3

Cheffins, B. R., \& Thomas, R. S. (2001). Should shareholders have a greater say over executive pay?: Learning from the US experience. Journal of Corporate Law Studies, 1(2), 277-315.

Clark, B., Birds, J., \& Boyle, A. J. (2011). Boyle and Birds' Company Law (8th ed.) Jordans.

Conyon, M., \& Sadler, G. (2010). Shareholder voting and directors' remuneration report legislation: say on pay in the UK. Corporate Governance: An International Review, 18(4), 296-312.

Copp, S. (2011). The Economic (and Moral) Case Against Capping Directors' Remuneration. Economic Affairs, 31(s2), 2-3.

Davies, P. L. (2008). Gower and Davies' Principles of Modem Company Law.

Dignam, A., \& Lowry, J. (2012). Company (7th ed.). Oxford.

Farrar, J. H. (2010). The global financial crisis and the governance of financial institutions. Australian journal of corporate law, 24(3), 227.

Ferrarini, G., Moloney, N., \& Ungureanu, M. C. (2010). Executive remuneration in crisis: a critical assessment of reforms in Europe. Journal of Corporate Law Studies, 10(1), 73-118.

French, D., Mayson, S. W., \& Ryan, C. L. (2014). Mayson, French \& Ryan on Company Law. Oxford University Press.

Hannigan, B. (2012). Board failures in the financial crisis: tinkering with codes and the need for wider corporate governance reforms (Parts 1 \& 2). Company Lawyer, 363.

High Pay Centre, (2014). 'FTSE 100 CEO Pay Briefing 2013-Have New Rules on Top Pay had Any Impact?' Retrieved from http://highpaycentre.org/pubs/high-pay-centre-briefing-the-effect-of-executive-pay-reforms

Hirt, H. C. (2004). Regulation of Directors' Remuneration: The German Approach, the DTI's Consultation Paper and the Way Forward. International Company and Commercial Law Review, 15(5), 154-165.

Joseph, E. A. (2012). Monitoring directors' remuneration, fat cat packages and perks of the office. Journal of Financial Crime, 6.

Karmel, R. S. (2004). Should a duty to the corporation be imposed on institutional shareholders. Bus. Law, 60, 1.

Kershaw, D. (2012). Company law in context: Text and materials (2nd, ed.). Oxford University Press.

King, P., Pau, L., \& Grapsap, R. (2013). Disclosure of Executive Remuneration in the UK: Recent Developments and US Comparison' (Practical Law). Retrieved from http://uk.practicallaw.com/1-523-1863?q=\&qp=\&qo=\&qe=\#a546928

Lee, J. (2012). Regulatory Regimes and Norms for Directors' Remuneration: EU, UK and 


\section{Macrothink}

International Journal of Learning and Development

ISSN 2164-4063 2017, Vol. 7, No. 3

Belgian Law Compared. European Business Organization Law Review (EBOR), 13(4), 599-637.

Lloyds Banking Group PLC. (2010). Annual Report and Accounts.

London Stock Exchange, (2012). Corporate Governance: For Main Market and AIM Companies.

Martin, C., \& Graham, S. (2010). Shareholder Voting and Directors' Remuneration Report Legislation: Say on Pay in the UK. 18 C G 296

Nakajima, C., \& Harry, W. (2012). Guest Editors' Introduction: Is the Desire to Embed Corporate Social Responsibility Within Organizations at a Crossroads?. International Studies of Management \& Organization, 42(3), 3-12.

Philip, W. J. (2015). Executive remuneration: regulatory reforms in UK company law. Int $J$ $L M, 57$.

Villiers, C. (1995). Executive pay: beyond control?. Legal Studies, 15(2), 260-282.

Wells, P. J. (2015). Executive remuneration: regulatory reforms in UK company law. International Journal of Law and Management, 57(4), 300-339.

\section{Official Materials}

Commission, 'Report on the Application by the Member States of the EU of the Commission Recommendation on the Role of Non-Executive or Supervisory Directors of Listed Companies and on the Committees of the (Supervisory) Board' (Staff Working Document) Sec (2007) 1021.

\section{Notes}

Note 1. ibid.

Note 2. Hutton v West Cork Railway Co (1883) 23 ChD 654.

Note 3. Guinness Plc v Saunders (1990) 2 AC 663.

Note 4. The Companies (Model Articles) Regulations 2008, SI 2008/3229.

Note 5. ibid art 23.

Note 6. ibid art 19(5)

Note 7. Ibid 358-360

Note 8. Technical Release, 'Financial and Accounting Duties and Responsibilities of Directors' (The Institute of Chartered Accountants, October 2008)

Note 9. CA 2006, s 420. 


\section{Macrothink}

International Journal of Learning and Development

ISSN 2164-4063 2017, Vol. 7, No. 3

Note 10. The Financial Reporting Council is the UK's independent regulator responsible for promoting high quality corporate governance and reporting to foster investment.

Financial Reporting Council, (2010) 'The UK Approach to Corporate Governance'.

Financial Reporting Council, (2012). 'The UK Corporate Governance Code' (Corporate Governance, September)

Financial Reporting Council, (2013). 'Directors' Remuneration' (Consultation Document, October)

Financial Reporting Council, (2014). 'The UK Corporate Governance Code' (Corporate Governance, September)

Financial Reporting Council, (2015).'Developments in Corporate Governance and Stewardship 2014' (Annual Report January)

Note 11. BIS published the Bill proposing under s 439 of CA.

Note 12. CA 2006, ss 420-422

Note 13. Department for Business Innovation and Skills, (2011). 'Executive Remuneration: Discussion Paper'.

Note 14. Department for Business Innovation and Skills, (2011).'The Future of Narrative Reporting: Consulting on a New Reporting Framework'.

Note 15. Department for Business Innovation and Skills, (2012) 'Executive Remuneration Discussion paper: Summary of Responses'.

Note 16. Department for Business Innovation and Skills, (2012). 'Executive Pay: Shareholder Voting Rights Consultation'.

Note 17. Dodd-Frank Wall Street Reform and Consumer Protection Act 2010

Note 18. Corporations and Markets Advisory Committee, (2011). 'Executive Remuneration Report' (Australian Government,)

Note 19. Commission Recommendation 2009/385/EC of 30 April 2009 Completing Recommendations 2004/913/EC and 2005/162/EC as Regards the Regime for the Remuneration of Directors of Listed Companies [2009] L120/28

\section{Copyright Disclaimer}

Copyright for this article is retained by the author(s), with first publication rights granted to the journal.

This is an open-access article distributed under the terms and conditions of the Creative Commons Attribution license (http://creativecommons.org/licenses/by/4.0/). 